\title{
LEARN FROM THE PAST FOR A SAFER TOMORROW: A Preview of Safety Congress 2020
}

\section{Roland Moreau}

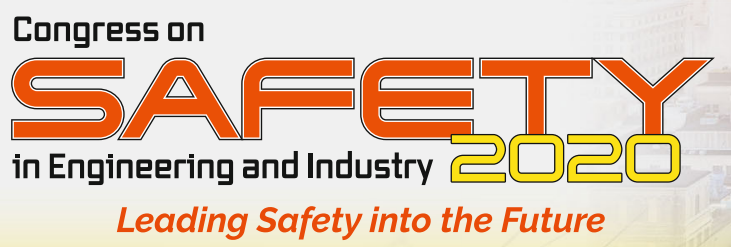

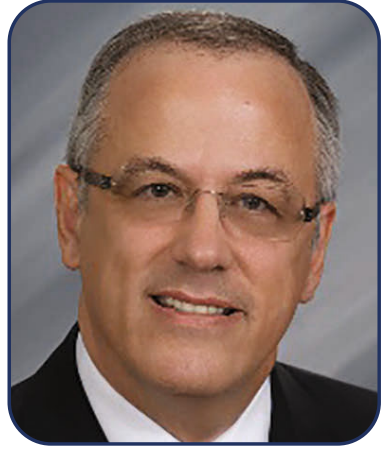

Roland Moreau
New applications of data and technologies are increasing profitability and productivity while making safer workplaces. Across industries, innovators are mitigating risks and ultimately saving lives by putting new practices in place, such as the use of structured management systems to improve processes, and automation and robots to remove workers from

dangerous situations. To join the conversation, I hope you plan to attend the inaugural Congress on Safety in Engineering and Industry 2020 (Safety Congress 2020) that is set for June 21-24, 2020, in Philadelphia, Pennsylvania.

Safety Congress 2020 is the first combined effort of eight professional societies and the National Academies to collaborate on safety successes and challenges, with representatives from each of these organizations actively serving on the program committee to plan the event. The United Engineering Foundation also has provided tremendous support to ensure its success.

Speakers are recognized experts representing the cross-section of disciplines of the partnering societies. Commonalities among all sectors present a basis for our keynote topics and plenary sessions: The Importance of Safety and Value of Networking across Sectors; The Value Proposition for Safety; Executing an Effective Risk Management Program; The Role of Technology \& Innovation in Improving Safety Performance; and Leading the Future of Safety by Learning from the Past.
The keynote and plenary sessions will introduce concepts and provide context for the breakout sessions, where attendees will explore safety issues in depth. Through collaboration and discussions, we will lay the groundwork to put new best practices in place, as well as to effectively avoid previous challenges that should be left in the past.

\section{CROSS-SECTOR COLLABORATION}

The combined efforts of the following organizations will provide attendees with unique networking and learning experiences.

\section{Sponsoring Societies:}
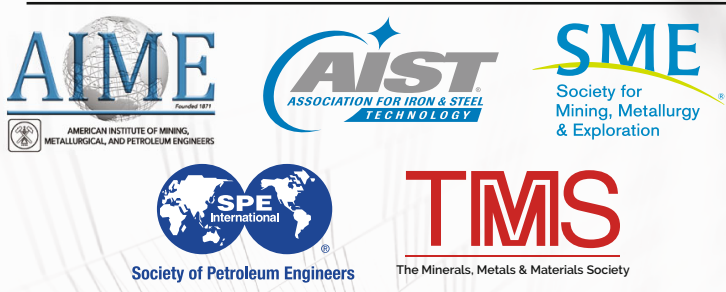

Co-Sponsoring Societies:

$$
\begin{aligned}
& \text { AIChE ASCE } \\
& \begin{array}{ll|l}
\text { SETTING THESTANDARD } & \begin{array}{l}
\text { The National } \\
\text { Academies of }
\end{array} & \begin{array}{l}
\text { SCIENCES } \\
\text { ENGINEERING } \\
\text { MEDICINE }
\end{array}
\end{array}
\end{aligned}
$$

Safety Congress 2020 is made possible with generous support from the United Engineering Foundation.

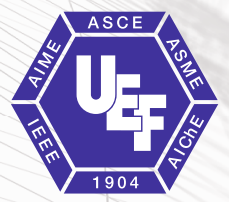




\section{Why Safety, Why Now}

For many years, regulators have required reporting of major incident data, and many industry associations have had various systems for collecting and sharing data related to major incidents. Given that all industries are subject to a certain level of regulatory-required safety incident reporting, a wealth of information is available stemming from non-reportable events, such as near misses, stop-work situations, and low-probability/high-consequence events.

Many companies have good internal systems for capturing and analyzing these data, but few opportunities have been pursued to share their knowledge based on the perception that the challenges faced by each industry are unique. Most practices in safety and risk management are not proprietary, and so they may be readily shared.

Successful approaches can be applied to different industry settings to improve safety overall. All industries, for example, implement practices for personnel and process safety, risk assessment and management, and the use of management systems and data analysis to guide decision making. It is also important to prepare university students prior to entering the workforce. Both academics and practitioners will bring their perspectives to bear at Safety Congress 2020.

This event will showcase safety management successes, address challenges, and provide networking opportunities to share experiences. The cross-sector audience creates a new environment for discussing case studies and identifying areas for collaboration on safety initiatives that fall outside the participants' normal spheres of influence.

\section{Anticipated Highlights}

Prominent speakers will share their perspectives, including a speaker from the National Safety Council's Campbell Institute, key regulator representatives from the Occupational Safety and Health Administration (OSHA) and the Mine Safety and Health Administration (MSHA), and university faculty.

Given NASA's expertise to ensure safety in all aspects of space flight, our opening keynote address will be delivered by former astronaut Jim Wetherbee, retired, U.S. Navy. Wetherbee has commanded five spaceflight missions and offers insights into dangerous businesses. He is the author of Controlling Risk-In A Dangerous World.

Chris Hart will deliver the dinner keynote address. He is a former member and chair of the National Transportation Safety Board (NTSB), chair of the Washington Metrorail Safety Commission, and founder of Hart Solutions LLC. Hart was instrumental in establishing the Airline Safety Reporting System (ASRS).

The breakout session on Safety Through Engineering Design will explore safety in the development and application of new technology and will be moderated by Robert Sims, a senior engineering fellow at Becht Engineering. The session's panelists include Gene Feigel,

\section{REGISTER TODAY}

Discount Registration Deadline: May 11, 2020 Housing Deadline: May 29, 2020

Space for this event will be limited. Complete your registration early to take advantage of discounted rates. And don't forget to book your room at the Marriott for the most convenient access to programming, networking, and other congress activities.

wWw.safetycongress.org

vice president of risk analysis at Hartford Steam Boiler Inspection and Insurance Company; Ken Balkey, retired director of Westinghouse Electric Company's Nuclear Engineering Program; John Gambatese, professor of civil and construction engineering at Oregon State University; Mihai Diaconeasa, assistant professor of nuclear engineering at North Carolina State University; and Mohammad PourgalMohamad, senior staff engineer at Johnson Controls Inc.

Other breakout sessions - such as Leadership Development; Integration of Safety in Regulatory Frameworks; Incident Investigation; Interfacing Workers and Machinery in an Industrial Environment; The Role of More Effective Data Management; Risk Identification and Tolerance; and more - are detailed in the Program section of the congress website at www.safetycongress.org.

\section{Make Your Plans}

Can you think of an industry where safety is not considered a high priority? I believe that a challenge for most industries and companies may be how to effectively learn from the past. So, I am hoping that this event will allow participants to equally share successes and challenges with the objective of everyone collaborating and partnering to make the work environment safer, including at the university level. Start making plans to join this conversation by visiting www.safetycongress.org for details. The new year is a time for commitments, and few are more worthwhile than one to safety.

Roland Moreau is the program chair of Safety Congress 2020, a trustee on the board of the United Engineering Foundation, and retired safety, health, and environment manager in the Upstream Research, Gas \& Power Marketing and Upstream Ventures business units at ExxonMobil. Moreau was also the 2018 president of the American Institute of Mining, Metallurgical, and Petroleum Engineers (AIME) and former board director for the Society of Petroleum Engineers.

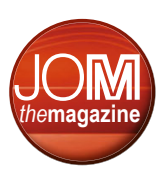

